\title{
A nova genética para além da gestão de riscos e promoção da saúde: prolegômenos ao conceito de Biodesign
}

| ${ }^{1}$ Murilo Mariano Vilaça, ${ }^{2}$ Alexandre Palma |

Resumo: A nova genética apontaria para uma nova era da metamorfose do humano, que seria marcada pelo protagonismo desse na seleção e aperfeiçoamento da sua natureza. Assim, o human enhancement tornariase uma realidade antropotécnica tangível. Esse artigo, inserido em uma pesquisa do campo da Ethics of Enhancement Human Beings, pretende excogitar um novo conceito para compreender nuances da chamada Genetic Age até agora aparentemente negligenciadas por outros dois conceitos já disponíveis, a saber, biopolítica e biossociabilidade. Para tanto, recorremos à revisão de parte da bibliografia sobre o tema e à análise e crítica desses conceitos, os quais focalizam a temática fundamentalmente através das noçôes de gestão de riscos e promoção da vida saudável. O objetivo foi apontar a parcial pertinência da grade de inteligibilidade fornecida por eles para compreender a nova genética. Destarte, apresentamos o conceito de biodesign como uma alternativa complementar. Com ele, esperamos oferecer, introdutoriamente, um conceito que apreenda, sobretudo, o que as possibilidades de artificialização da vida humana representam para além de uma nova forma de gestão de riscos/promoção da saúde.

> Palavras-chave: Nova genética; gestão de riscos; biopolítica; biossociabilidade; biodesign.
1 Mestre em Educação (PPGEUFRJ); Doutorando em Filosofia (PPGF-IFCS/UFRJ); Doutorando em Educação pelo Programa de Pós-Graduação em Educação (ProPEd - UERJ). Endereço eletrônico: contatoacademico@ hotmail.com

2 Docente do Programa de Pós-Graduação em Educação Física (UFRJ); Doutor em Saúde Pública pela ENSP/FIOCRUZ. Endereço eletrônico: palma alexandre@yahoo.com.br

Recebido em: 08/09/2010. Aprovado em: 27/02/2011. 


\section{Introdução}

As inovações biotecnocientíficas que a nova genética traz e promete disponibilizar futuramente sugerem a possibilidade de ingressarmos em uma nova fase no processo de metamorfose do humano, na qual o homem assumiria o protagonismo no processo de seleção e evolução, e não mais seria um objeto passivo em relação à natureza. Esta possibilidade encontraria no human enhancement de bases biotecnocientíficas seu catalisador, na medida em que ele concretizaria o secular desejo humano de aperfeiçoar artificialmente suas capacidades físico-mentais ou comportamentais. Assim, o humano, como compreendemos, estaria próximo da obsolescência.

Atualmente, variados conceitos são utilizados e diferentes perspectivas se posicionam na discussão acerca da nova genética. Atentos a traços do recente debate entre os chamados bioconservadores e transumanistas, o presente artigo visa a analisar dois conceitos que compóem o debate bioético, a saber, biopolítica e biossociabilidade. O objetivo é identificar quais inteligibilidades dão às características da nova genética, bem como às possibilidades de mudanças decorrentes dela, apontando, por outro lado, alguns dos seus limites.

Nossa hipótese é que são parcialmente adequados, porque focalizam as noções de gestão de riscos e de promoção da vida saudável, o que, no nosso entendimento, não seria suficiente. Destarte, apresentaremos, por fim, o conceito de biodesign como uma alternativa complementar àqueles, uma vez que esse daria conta de alguns aspectos negligenciados. Para tanto, recorreremos à revisão de parte da vasta bibliografia sobre o human enhancement e à especulação filosófica acerca daqueles dois primeiros conceitos, metodologia que servirá de base para a apresentação do de biodesign.

\section{Governando a vida: notas sobre biopolítica}

O conceito de biopolítica expressa um visada histórica sobre um modo de governo da vida, sobre a entrada da vida biológica, não individual, mas coletiva, em uma ordem política baseada, fundamentalmente, nas ideias de gestão de riscos e promoção da saúde dos seres vivos de uma população. Vida positivada, como alvo de promoção, investimento, preservação, majoração, passa a ser, do ponto de vista foucaultiano, uma preocupação intensiva das formas de governo modernas, das governamentalidades, especificamente da sua face biológica, cujo alvo é uma 
população de seres vivos (FOUCAULT, 2008). Natalidade e mortalidade, níveis

de saúde e doença, duração e qualidade da vida são alguns alvos da regulação de populações (FOUCAULT, 2003). A vida entrava, então, em uma lógica corpo-espécie, atenta ao ser vivo e aos processos biológicos que lhe dão suporte, preocupação biopolítica que encontrou no aparato de saberes das biociências uma forma de regular e controlar a vida, ou seja, "toda uma série de intervenções e controles reguladores” (FOUCAULT, 2003, p. 131).

A biopolítica inaugurou aquilo que se pode chamar de era do imperativo da saúde (FOUCAULT, 2007). Os processos vitais são vistos como possuindo uma mecânica própria a ser compreendida, cuja harmonia deve ser mantida, a fim de promover uma vida saudável. Isto configuraria a atuação do biopoder, das suas tecnologias pautadas pela lógica dos dispositivos de segurança, os quais operariam pela regulação estatística da relação entre caso-riscoperigo-crise, própria das técnicas profiláticas de vacinação, procedimento da variolização ou inoculação, segundo Foucault (2008). Isso representa a tomada da vida como objeto das biociências e da estatística, condição de possibilidade do surgimento de técnicas preventivas e generalizáveis no que se refere à população, com vistas à normalização.

A prevenção globalizante é especialmente relevante. Consoante a biopolítica, ela atua, sobretudo, através da noção de saúde pública, o que está intimamente ligado àquilo que Foucault (2007) denominara de medicalização da sociedade. Isso indica que se tratava de medidas de conjunto e não individuais. Saúde pública e medicina social, constituindo um complexo processo de normalização, estão associadas ao poder médico de previsão e de correção de estilos de vida de dado conjunto de seres vivos.

O poder político da medicina, marcado por esse olhar calculista, "consiste em distribuir os indivíduos uns ao lado dos outros, isolá-los, individualizá-los, vigiá-los, um a um, constatar o estado de saúde de cada um, ver se está vivo ou morto e fixar, assim, a sociedade em um espaço" (FOUCAULT, 2008, p. 89). A medicina, entendida como técnica geral de saúde, de gestão de riscos, assume um lugar cada vez mais importante na maquinaria de poder a partir do século XVIII. Conforme a interpretação foucaultiana da modernidade, nesse século, nasce um tipo de poder que está relacionado a um saber médico-administrativo, isto é, "uma ascendência político-médica sobre uma população que se enquadra 
como uma série de prescrições que dizem respeito não só à doença, mas às formas gerais da existência e do comportamento" (FOUCAULT, 2008, p. 202). Isolar, individualizar, fixar (em um domicílio, por exemplo), esquadrinhar, dividir, inspecionar, controlar, registrar etc. são ações ligadas a práticas que visam a promover um minucioso controle social, pautado na previdência sobretudo, diretamente ligadas ao saber médico.

Como vimos, biopolítica é o conceito potente para entender as relações entre saberes biomédicos, exercício do poder político e controle de populações, especialmente nos termos de regulações e controle globais, generalizantes, combate a comportamentos de riscos e promoção da vida saudável. Entretanto, conquanto a nova genética seja uma forma de articulação entre saberes biocientíficos com possibilidades de aplicação política similar, a lógica presente na biopolítica não parece contemplar a nova genética por pelo menos duas razōes: (1) ainda que a nova genética permita uma intervenção coletiva, sobre populações, por exemplo, para erradicar patologias endêmicas ou deficiências congênitas marcantes em dada população, ela não se restringe a esse enfoque, como veremos a seguir; (2) enquanto a biopolítica visava a um governo pautado na produção de uma vida normalizada, cujo fim era uma vida saudável, a nova genética não se aplica exclusivamente à promoção de saúde, mas amplia sua utilidade para o design de características que extravasam o binômio saúde-doença, servindo à arquitetura de projeto racional de boa vida, uma espécie de estetização biotecnológica de si e da descendência, ou seja, de corpos individuais.

\section{Vida e condição pós-humana: genética, metamorfoses e autocriação}

O advento da biotecnociência tornaria cada vez mais factível a radicalização da artificialização da vida humana, quer dizer, desde sua base genética. Aduzindo a (imprecisa) contraposição feita por Habermas (2004) entre natureza externa e interna, se já temos algumas possibilidades acerca daquela natureza, no que diz respeito a essa, as técnicas advindas da genética seriam a chave para uma intervenção ainda mais radical. Uma intervenção genotípica (natureza interna) tornaria a fenotípica (natureza externa) algo ultrapassado. Desde o momento pré-nascimento, poder-se-ia configurar que tipo de ser humano se quer criar, que descendência se deseja ter. 
No DNA, estaria todo o protos, a primeira e principal matéria da qual tudo que é vivo se constituiria. Sendo assim, falar em DNA seria tratar de algo que poderia ser, até hoje, o mais próximo que chegamos daquilo que chamamos de origem da vida. $\mathrm{O}$ homem pode dominar um conhecimento com alcance espetacular, considerando que todos os seres vivos são constituídos por DNA, ou seja, a linguagem genética é universal.

Tal perspectiva soa determinista e, em certa medida, reducionista, sendo criticada por pensadores de diferentes perspectivas. Valenzuela (2005), por exemplo, destaca que, com a genética, pode-se compreender que as raízes biológicas da liberdade e da condição cultural do humano estejam na própria natureza do genoma humano. Ainda de acordo com a autora, "genética permite uma espécie de abertura, de hiato, uma margem de indeterminação e 'nãoprogramação' (ou, talvez, sobredeterminação) que torna possível, justamente, o domínio da possibilidade e da liberdade" (VALENZUELA, 2005, p. 24).

Lewontin (1998, p. 52) concorda que a vida não está "toda” nos genes. Segundo ele, mesmo "uma versão mais sofisticada do determinismo genético (que) concorda que os organismos são uma consequência tanto das influências ambientais como das influências genéticas, mas descreve as diferenças entre os indivíduos como diferenças de capacidade", não daria conta de como a vida se constitui através da interação dessas influências. Assim, considerando a incontornável importância do meio ambiente sobre a constituição do humano, o biólogo deixa clara a sua contrariedade à ideia do determinismo genético ou biológico.

Daniels (2009), por seu turno, demonstra a sua rejeição à ideia de natureza humana biológica como algo essencial, fixo, imutável, afirmando que o humano, assim como a "mosca de fruta" (fruit fly), possui, no máximo, uma natureza disposicional, expressa pela relação triádica entre população-disposição-seleção, o que destoa completamente da visão, por exemplo, de Fukuyama (2003), que acredita que há algo, uma natureza humana, que independe completamente da relação humana com fatores ambientais. Para aquele, a natureza de dada espécie, a manifestação fenotípica de dado genótipo, depende necessariamente do ambiente no qual está inserido.

Outra crítica a qualquer forma de determinismo naturalista com teor normativo, ou seja, à ideia de natureza humana e à sua função normativa, é-nos apresentada por Buchanan (2009). Segundo ele, recorrer ao conceito de natureza 
humana para iluminar o debate acerca da "ética do aperfeiçoamento" (ethics of enhancement) é um erro, uma vez que ele tende a obscurecê-lo, haja vista suas imprecisões. Além disso, argumenta que a natureza humana, de um ponto de vista plausivel, não é absolutamente boa, mas possui aspectos maus, de tal modo que, por si só, a sua alteração não constituiria um mal. Quer dizer, se há “aspectos maus" (bad characteristics), o uso da biotecnologia com vistas ao aperfeiçoamento, que poderia eliminá-los, seria um bem.

Essa perspectiva, como se pode prever, possui adversários. Entre os pensadores que veem com ressalvas os avanços biotecnocientíficos, compartilhando o temor ante a biotecnociência, citamos Habermas (2004), Sandel (2007), Fukuyama (2003) e Lewontin (1998), os quais não podem ser enquadrados em uma mesma perspectiva, mas, a despeito de importantes particularidades, preenchem alguns requisitos daquilo que Bostrom e Savulescu (2009) denominam de visão bioconservadora (bioconservativeview). Assumindoumaposiçãoantiaperfeiçoamento (anti-enhancement), tais autores defendem a indisponibilidade do patrimônio genético humano à tecnicização, pois as tecnologias de aperfeiçoamento humano comprometeriam a dignidade humana.

Essa posição polariza com a dos chamados transumanistas (transhumanists view), que assumem uma posição pró-aperfeiçoamento (pro-enhancement) ou pela bioliberação (bioliberation), para os quais um amplo rol de técnicas de aperfeiçoamento deve ser desenvolvido e as pessoas devem ser livres para usálas, transformando-se de acordo com sua vontade. Segundo essa perspectiva, até mesmo os indivíduos considerados saudáveis seriam beneficiados pelas inovaçōes biotecnológicas.

Nesse sentido, um importante acontecimento que elevou a um nível superior, ainda mais promissor ou temerário, a compreensão da vida e as possibilidades de intervenção sobre a constituição dos seres vivos foi o, para alguns, bem-sucedido Projeto do Genoma Humano (PGH), que, em 2003, anunciou ao mundo o acesso ao acervo de informações da estrutura biológica humana. A artificialização da vida possibilitada, em tese, pela manipulação genética, com abertura à eugenia, entrou em uma nova era. Rabinow (1999), apesar de não devotar total credulidade à essa visão, afirma, com um tom relativamente prudencial, "que a nova genética deverá remodelar a sociedade e a vida como uma força infinitamente maior do que a revolução na física jamais teve [...]” (grifo nosso, p. 143). 
De acordo com Rabinow (1999, p. 138), "genoma é a totalidade do material genético (genes) no conjunto de cromossomos de um organismo específico". A decifração do genoma humano constitui, para alguns, o fato mais importante da história da humanidade, sendo crucial para a compreensão da natureza humana. A capacidade de ler o genoma humano - o que movimentou investimentos políticos, científicos e, sobretudo, financeiros, privados ou não, imensos, gerando uma verdadeira corrida pela decifração do genoma humano - permitiria compreender nossas origens, nossa evolução, natureza e constituição corpóreomental, o que revolucionaria todas as ciências, não só as biomédicas.

Buchanan et al. (2001) apontam que o PGH já propicia dois tipos de intervenção genética, a saber, intervenção direta e intervenção indireta. No primeiro tipo, eles enquadram a terapia genética, através da qual genes normais ou "desejáveis" (desirable) são inseridos em "células somáticas" (body tissue) ou "germinativas" (germline cells - gametes, sperms or eggs, or embryos); e a cirurgia genética (gene surgery), que opera através do "desligamento" (switched off) de genes anormais ou indesejáveis, a fim de evitar que produzam distintos efeitos considerados como nefastos.

Do lado das intervenções indiretas estariam a farmacologia genética (genetic pharmacology), que visa a usar o conhecimento genético para criar drogas baseadas em genes normais; a seleção de embriôes (embryo selection), que envolve três estágios, a saber, a coleta, a análise genética (DNA analysis) e a implantação do embrião cujas características sejam preferidas pelos pais; o teste genético de intervenção reprodutiva (reproductive genetic testing interventions) e o teste genético de intervenção terapêutica (therapeutic genetic testing interventions), que, grosso modo, são técnicas, respectivamente, de fornecimento de informações para tomadas de decisões reprodutivas e de amenização (ameliorate) de doenças genéticas já existentes num indivíduo.

Tais diferenciações são pertinentes e contribuem para o entendimento da miríade de possibilidades que a nova genética vem oportunizando ou prometendo oportunizar. Considerando um período mais ou menos recente, podemos citar as já consagradas técnicas reprodutivas, tal como a fertilização in vitro - também conhecida como reprodução medicamente assistida -, que, no final da década de 1970, prometia solucionar o "problema" da infertilidade. Esse primeiro exemplo de técnica de artificialização da vida, que causou uma 
espécie de cesura biotecnocientífica, serve-nos para problematizar algumas teses dos polos supracitados.

Sobreos temores dos bioconservadores acerca das consequências daartificialização da vida humana, por que - embora à época muitos alardeassem que aquela técnica iria colocar o humano em risco - aquela técnica não é mais considerada uma ameaça, mas sim uma terapia? Por que uma técnica artificializadora, que visa a contornar uma característica biológica específica presente em alguns indivíduos da espécie - afinal, tomar a infertilidade como um problema não é algo trivial, pois, se considerarmos a tese de Sandel (2007), de que a natureza possui uma sabedoria ou prudência (wisdom nature), alguns exemplares da espécie deveriam ser estéreis naturalmente, a título, por exemplo, de controle de natalidade e aperfeiçoamento, o que tornaria a esterilidade uma necessidade naturalmente determinada - não represente mais uma ameaça, sendo, inclusive pelos bioconservadores, vista como normal, além de moral e cientificamente aceitável?

Por outro lado, o dos transumanistas, que defendem a tese do pós-humano, por que a reprodução artificial não promoveu o nascimento de um novo homem? Ademais, diante de uma infinidade de técnicas artificiais de gestão biológica da vida e, em certo sentido, de melhoramento, tais como fármacos, incrementos nutricionais, próteses, implantes e transplantes, os quais poderiam certamente promover uma profunda alteração quanto à nossa compreensão do que é ser humano, por que isso ainda não ocorreu? O que, portanto, garantiria que o pós-humanismo advirá em razão das técnicas genéticas mais atuais? Dias e Vilaça (2010), partindo do princípio de que a natureza humana não é algo estável, imutável e universal, contestam a ideia transumanista, argumentando não ser evidente que alterações na constituição do humano alterariam, necessariamente, a nossa compreensão do que é ser humano. $\mathrm{O}$ incremento nutricional entre os séculos XIX e XX, visando ao aumento artificial da estatura média da população, por exemplo, não parece uma ameaça ao humano. Destarte, considerando os argumentos apresentados por eles, nem estaríamos comprometendo a natureza humana, tampouco dando origem a um novo humano, mas sim dando continuidade a investimentos de controle, promoção e aperfeiçoamento seculares, só que através de novas técnicas.

Além das já supracitadas modalidades de intervenção genética, ainda no campo das técnicas já disponíveis, podemos ainda citar a PCR (Polymerase Chain Reaction) e o PIGD (Preimplantation Genetic Diagnosis). Mas há algumas cuja 
eficácia não foi comprovada. Dentre elas, destacam-se a clonagem e a terapia genética com uso de células-tronco humanas. Apesar de amplamente testadas e divulgadas, não sabemos se serão disponibilizadas, ou seja, se as pesquisas serão bem-sucedidas, fornecendo resultados que gerem benefícios à humanidade.

Parece-nos que, de um modo ou de outro, estamos diante de um campo comum, qual seja, o do investimento no human enhancement. A escolha racional e artificial de características corporais, especialmente as chamadas "secundárias", por exemplo, cor dos olhos, o que Habermas (2004) chama de eugenia positiva; a prevenção de doenças pré-nascimento através de uma intervenção direta ou indireta, chamada por Habermas de engenia negativa; bem como o tratamento pós-nascimento (intervenção indireta apenas), terapia nos termos dele, expressam iniciativas que compartilham, a nosso ver, a mesma intenção de tornar o humano algo "melhor", menos limitado, mais saudável, no limite, promovendo as condições de possibilidade disponíveis no momento à realização de um projeto tangível de boa vida. Aliás, se a fronteira entre prevenção e tratamento já merece um olhar atento quanto aquilo que visa a distinguir, muito mais problemática, para nós, é aquela que separaria o aperfeiçoamento da terapia. Afinal, se agimos ativa e racionalmente, visando à artificial (humana e não natural) (re)constituição biológica de dado indivíduo, não é imperativo admitir que pretendemos melhorar a vida, torná-la mais digna, feliz ou bela? De acordo com Glover (2006), qualquer iniciativa que vise a alterar uma característica humana, ainda que não seja altruísta, pretenderia melhorar a vida e, quiçá, tornar o mundo um lugar melhor.

Evidentemente, o termo melhor suscita mais controvérsias do que consensos. Para Tugendhat (apud VALENZUELA, 2005), a técnica genética, promovida em larga escala pelo PGH, coloca-nos desde já, e colocará mais intensamente nos próximos anos, frente a problemas extremamente complexos e novos, que requererão julgamentos e decisões cujas repercussões são graves. Para ele, os progressos advindos dos avanços da biotecnologia abrem um campo de ação inédito, diante do qual não podemos recorrer tão somente aos critérios do desejável ou não, do lícito ou ilícito.

O que parece constranger a muitos é a iminente possibilidade da autocriação e autosseleção do humano. Buchanan et al. (2001), bem como Agar (2004) e Glover (2006) focalizam exatamente a dimensão da escolha. Sem tergiversar os riscos envolvidos em toda ação eletiva, eles investem no ponto fulcral da 
crítica habermasiana, a saber, a eugenia liberal e a sua aposta na positividade da escolha. $\mathrm{Na}$ análise das mudanças da era genética (challenges of the genetic age), Buchanan et al. (2001) esposam a "possibilidade de escolha" (from chance of choice) como um elemento que deve ser disponibilizado aos humanos, até mesmo sob a insígnia da justiça distributiva dos bens genéticos que um Estado justo deve garantir, a fim de cumprir a obrigação de prevenir danos. Agar (2004) e Glover (2006), bem como Savulescu (2001) e Savulescu e Kahane (2009), têm trabalho a oportunidade da escolha de que descendência se quer ter como uma atividade tipicamente humana de busca por uma "boa vida" (good life). Savulescu, especialmente, com a ideia do principle of procriative beneficence, tem afirmado que a intervenção com fins de seleção e aperfeiçoamento não é uma mera possibilidade, mas sim um dever moral, um imperativo, dos pais para com a sua descendência, o que, é claro, pode ser questionável. Ele chega a defender a ideia do enhancement as a basic human right. ${ }^{1}$

Lafont (2003), por sua vez, na sua crítica a Habermas, parece corroborar a perspectiva de que não há imoralidade alguma na escolha da descendência. Denominando de ingenuidade idealista, problematiza a ideia de que os pais, ao interferirem no genótipo, estariam solapando certas capacidades humanas - autonomia, autenticidade e autocompreensão ética. Ela argumenta que é um fato, portanto, algo constatável, que os pais, incontornavelmente, interferem nas possibilidades de constituição genética e fenotípica de seus filhos, além de investir boa parte de seus esforços na educação dos mesmos, reduzindo, assim, as suas possibilidades existenciais.

Isso aponta para aquilo que vem sendo denominado de perspectiva transumanista (transhumanists view). Consoante Dupuy (2009), transumanistas como Bostrom se consideram humanistas racionais. Para Dupuy (2009), é justamente isso que os torna perigosos, pois, mais uma vez, a ciência e a técnica podem solapar a razão e a liberdade humanas. Habermas e Lewontin, ambos já citados, compartilham essa visão, defendendo que o humano não deve estar submetido aos ditames arbitrários e, logo, questionáveis da tecnociência. Lewontin, ao lado de Rabinow, inclusive desconfiam do prometeísmo da biotecnologia, ou seja, de que ela cumprirá tudo que promete.

Apesar de esposar certo grau de incerteza, Rabinow, por exemplo, parece considerar a real possibilidade de concretização do que ainda está em nível de 
promessa. Na obra na qual fez uma breve história da biotecnologia (RABINOW, 1996), analisando o que chama de emergência da indústria biotecnológica, na década de 1970, suas considerações parecem tomar como factível, ainda que não atual, a concretização daquilo que a retórica da biotecnologia vem propugnando. Citando a caracterização do capitalismo tardio de Fredric Jamenson, segundo a qual o capitalismo global estaria alcançando uma penetração em uma escala nunca antes vista, a saber, ao nível da natureza, o que implicará graus de manipulação e transformação inéditos que permitirão condições artificiais de controle das variáveis dos processos biológicos mais complexos, Rabinow (1996) se mostra relativamente preocupado com suas consequências. Ele aduz o exemplo de como o avanço das biotecnociências pode alterar o estatuto de organismos e células, isto é, de produtos da natureza, não patenteáveis, portanto, para meros objetos de novos inventos, consequentemente patenteáveis. Ora, caso Rabinow sequer cogitasse uma relevante probabilidade de concretização dos discursos dos biotecnólogos, um possível e, sobretudo, temível patenteamento da natureza não estaria no horizonte de suas questôes.

Essa é uma importante mudança de postura frente à biotecnologia, pois Rabinow, num artigo originalmente publicado em 1992 - logo, anterior ao texto supracitado, de 1996 -, assumia uma postura, por assim dizer, meramente descritiva, nem contra nem a favor. Então, pode-se conjecturar, essa mudança de postura pode representar a constatação da iminente concretização de biotécnicas revolucionárias, o que o despertou da posição de "neutralidade" antes assumida, fazendo-o tomar uma posição quiçá bioconservadora, no mínimo crítico-prudencial.

Os transumanistas, ao contrário, argumentam que o uso da biotecnociência amplia e ampliará aquelas capacidades humanas supracitadas. Tal perspectiva defronta-se evidentemente com as teses bioconservadoras, uma vez que ela se baseia na hipótese de que as técnicas de manipulação permitirão que o homem realize aquilo que os transumanistas entendem ser a sua essência, isto é, dominar, inclusive a própria natureza. Em certo sentido, esse era um horizonte tipicamente humano desde a antiguidade. Dominar a natureza externa e interna sempre foi uma obsessão humana.

Essa visão metafísica da subjetividade humana, que pode ser encontrada já em Descartes, mas especialmente em Heidegger, para o qual a cibernética, entendida como o governo pelo cálculo, é o auge do pensamento calculador e 
representa a apoteose do humanismo (DUPUY, 2009), serve ao transumanismo como fundamento, como justificação. Afinal, por que o homem, sendo capaz de desenvolver a sua essência dominadora, ampliando o seu espectro de possibilidades, abriria mão disso? Tal opção não poderia ser compreendida como desumanizadora? Os transumanistas diriam que o humano precisa transcender a si mesmo, elevando as suas capacidades a níveis ainda mais excelentes, e que não há qualquer justificativa para que isso não seja efetuado também através do uso de biotecnologias. Os críticos, como ressalta Dupuy (2009), dizem que o risco é que o ser humano simplesmente desapareça em meio à sua autoartificialização criadora, uma forma de self-design que descaracterizará o humano tal como o concebemos.

Recorrendo à análise deleuzeana para pensar como a nova genética alterará o modo de conceber o ser humano, tal temor não se sustentaria. Da afirmação de que existe uma espécie de princípio geral em Foucault, que “toda forma é um composto de relações de forças" (DELEUZE, 2005, p. 132), pode-se, tendo em vista a suposição de que a nova genética coloca novas forças em jogo, inferir que uma nova forma-Homem estaria em vias de ser criada. Mas é apenas uma nova forma. Dessa feita, o transumano seria somente um novo estágio, que não podemos antecipar se é "bom" ou "ruim", até porque não teríamos o homem em si como parâmetro de comparação. Desse ponto de vista, a ideia de póshumano, excogitada por alguns, também não faria sentido. Não há humano, logo, pós-humanos. Porém, em síntese, o humano teria naturalmente uma condição, possuindo a característica de ser metamorfoseável. Em certo sentido, ser "humano" é justamente se modificar, recriar ou se autocontrolar.

As expectativas de ambas as partes supracitadas merecem análises atentas, não suscetíveis a discursos ficcionais, demarcados por posições extremadas, pois lidamos com possibilidades que dependem ainda da concretização e disponibilização das técnicas pesquisadas. Além disso, mesmo quando disponíveis, certo tempo terá de ser percorrido, para que suas consequências possam ser efetivamente avaliadas. Assim, sobre o nascimento de um novo humano como resultado da implementação de novas técnicas de artificialização da vida humana, estamos no campo das especulações, as quais, quanto mais prudentes mais adequadas, pois evitarão, ao mesmo tempo, excesso de temor ou de confiança. 


\section{Sobre o conceito de biossociabilidade:}

uma radicalização da previdência

Vejamos como Rabinow compreende esse novo campo de possibilidades, o qual representa uma revolução sem precedentes, analisando o seu conceito de biossociabilidade. Para Rabinow (1999), biossociabilidade é o resultado processual do ainda em curso progresso da nova genética, que deixará de ser uma mera metáfora biológica, tornando-se uma grade lógica de uma nova rede de circulação de termos de identidade e lugares de restrição, em torno do qual surgirá um modo inédito de autoprodução dos sujeitos. Conforme o autor, os dois pólos de atuação do biopoder, corpo e população, serão rearticulados através de uma racionalidade pós-disciplinar. Nesse contexto, a natureza será remodelada pela técnica, tornandose, finalmente, artificial. Segundo ele, caso esse projeto venha a termo, a separação entre cultura e natureza poderá ser superada (RABINOW, 1999).

$\mathrm{Na}$ biossociabilidade, segundo Rabinow (1999), novas identidades e práticas individuais e grupais serão formadas. Ainda segundo o autor, os grupos não serão formados mais em torno de certos valores, bens, ideais, língua, isto é, elementos socioculturais, mas sim de seu mapa genético, de sua afecção gênica mais propriamente. Isso, para ele, não é uma hipótese, pois "haverá, sim, grupos formados em torno do cromossomo 17, locus 16.256, sítio 654.376, alelo com substituição de uma guanina" (RABINOW, 1999, p. 147). E é justamente isso que ele entende por biossociabilidade, um modo de identificação que é fruto do esquadrinhamento ou mapeamento genético, possibilitando uma espécie de união em torno de um destino geneticamente fundado e supostamente previsível.

Os pontos-chave, para Rabinow, são dois e estão em íntima relação: por um lado, a nova genética, que enseja o surgimento da biossociabilidade, inaugurará uma nova gestão dos riscos, haja vista as novas tecnologias criadas, tais como o polymerase chain reaction e o preimplantation genetic diagnosis; por outro, alterará radicalmente as nossas práticas sociais, os modos como nos identificamos, a nossa visão ética, o que estará em um novo regime de verdade (biocientífica).

$\mathrm{Na}$ esteira da dessacralização da vida e de secularização do governo do homem inaugurada pela modernidade, que, sobretudo através a ciência, destituiu parcialmente o divino, a biogenética descortinou o destino dos sujeitos, conforme provocou Watson (2003), uma vez que ele não é mais lido nas estrelas, mas sim 
nos genes. Tal assertiva, carregada de prometeísmo e de credulidade, ainda está sub judice, inclusive científico, não configurando um campo de certezas, mas, no máximo, de possibilidades. Todavia, esse parece o registro no qual Rabinow faz a sua pesquisa etnográfica de "descrição" do que, para ele, está acontecendo.

Um aspecto da argumentação de Rabinow que merece destaque e atenção especiais é a distinção quanto ao tipo de gestão dos riscos que excogita. Como vimos, Foucault analisa o tipo de gestão de riscos inventado pela modernidade para definir a biopolítica. Rabinow usa uma contraposição entre tipos de gestão de riscos para demarcar a emergência de uma nova sociabilidade. Para ele, "podemos ver os indícios da dissolução da sociedade moderna acontecendo nas transformações recentes do conceito de risco" (RABINOW, 1999, p. 144). Rabinow apresenta uma distinção entre a modernidade disciplinar e pósdisciplinar nos termos de Robert Castel, a partir da obra A gestão dos riscos, de 1981. Enquanto uma administração tecnocrática de diferenças, ela implica uma mutação de tecnologias sociais, visando, sobretudo, à radicalização da prevenção. A ideia é reduzir a intervenção terapêutica a partir de um estímulo intensivo e extensivo da autogestão dos riscos pelo próprio sujeito. Objetiva-se elevar a profilaxia a níveis nunca antes possíveis, ou seja, ao nível das raízes genéticas da vida humana, de modo que a gestão dos riscos não seja mais um investimento sobre o controle de estilos de vida, sobre a vida, por assim dizer, "em ato", mas a vida ainda "em potência". O foco é a artificialização da vida e da natureza humanas, no registro do enhancement dos seres humanos (MURRAY, 2009).

Um último aspecto do conceito de biossociabilidade que merece ser citado é a possibilidade que discutimos acima, a saber, a artificialização da vida e natureza humanas. Tomando, sobretudo, a reflexão de François Dagognet desenvolvida na obra La maitrise du vivant, de 1988, que pode ser tida como um elogio explícito, porém não ingênuo, à artificialização, Rabinow, ainda que de modo tácito, parece elevar a sua credulidade e aposta na nova genética muito mais além da mera descrição que anunciou querer fazer com seu olhar etnográfico. Por exemplo, ao citar, e não problematizar ou criticar, a tese dagognetiana de que, desde os gregos, um equívoco foi cometido, qual seja, a arbitrária separação entre o natural (positivado) e o artificial (negativado), constituindo, assim, uma tradição naturalista, uma das "mentiras mais duradouras" (RABINOW, 1999, p. 153), da qual, considerando o potencial nietzschiano, podemos nos livrar 
na atualidade. Em conformidade com Buchanan (2009), Sloterdijk (2000) e

Daniels (2009), o valor tradicionalmente dado à natureza é contestado, dando lugar à visão de natureza como um bricoleur cego, um jogo de combinações que possui uma lógica elementar, mas que produz uma infinidade de diferenças potenciais. Questionando a tradicional noção de natureza, conforme cita Rabinow (1999), Dagognet afirma que a crítica ao artificial, entendido como uma cópia menoscabada do natural, é composta em torno de três axiomas questionáveis: (1) o artificial não é tão bom quanto o natural; (2) a vida é autoprodução; e (3) a homeostase (autorregulação) é a regra d'ouro.

Partindo da suposição de que a palavra "natureza" deve ser entendida como uma "polifenomenalidade explícita de apresentação [...], a atitude natural do homem seria facilitar, estimular, acelerar a sua expansão: variação temática, não rigor mortis" (RABINOW, 1999, p. 154). Com essa frase emblemática, Rabinow encerra a sua abordagem, inclinando-se favoravelmente à ideia de que o termo manipulação pode, ao mesmo tempo em que indica possibilidades temíveis de dominação e disciplinarização, representar um imperativo aperfeiçoador do humano.

\section{A vida para além da biopolítica e biossociabilidade: prolegômenos ao conceito de biodesign}

A partir da discussão desenvolvida, inferimos que os conceitos analisados servem parcialmente para compreender a nova genética e aquilo que ela desenvolve e pode desenvolver. Biopolítica traduz um modo de governo operado através da lógica dos dispositivos de segurança, visando ao controle dos riscos, à promoção da vida e à normalização através da gestão dos processos biológicos de uma população.

Notadamente, o conceito de biopolítica se apresenta como mais inadequado, uma vez que, como se sabe, na genealogia foucaultiana, como uma perspectiva histórica de pesquisa, não se colocava fatos ou problemas imaginários ou futuros, mas históricos. Assim, não estava no horizonte do conceito foucaultiano analisar a nova genética. Inobstante, cabe considerar que a potência da reflexão foucaultiana não está necessariamente adstrita ao tempo e aos fenômenos analisados. Destarte, a grade de inteligibilidade fornecida por aquele conceito não é absolutamente inútil para compreender alguns traços que a nova genética possui, até porque são elementos mais ou menos antigos, que ela apenas remodela, opera de modo inovador. Por exemplo, a lógica da prevenção emergente na biopolítica não é 
superada, mas radicalizada. O que existe é uma espécie de relativa modularização de técnicas e de alcance, mas não de todos os objetivos. Em suma, há certo anacronismo, mas ele não é total.

A noção de biossociabilidade representa uma nova rede de circulação de termos de identidade e lugares de restrição, cujo eixo orbital será o mapeamento genético que determinará probabilidade do desenvolvimento de certa afecção ou a presença de uma característica fenotípica. Ao que parece, esse conceito, forjado especificamente para dar conta da eclosão da nova genética, ressalta justamente essa modularização supracitada. Rabinow não tergiversa o fato dela se configurar como uma gestão de riscos, mas defende que traz novidades procedimentais e mudanças quanto ao poder de antecipação. Outro traço desse conceito que denota a sua maior capacidade respondente às necessidades de compreensão da biotecnociência é a menção à artificialização. Para nós, a instrumentalização do humano pela tecnociência é, seguramente, o traço mais relevante da nova genética, tornando-a uma relação de poder-saber do humano sobre si mesmo inédita.

Embora a saúde não esteja fora de questão, não parece se constituir necessariamente como um imperativo, tal como na modernidade. Rivalizando com ela em termos de protagonismo surge uma nova e temível demanda ou possibilidade: o self-design dos sujeitos. Não é só a seleção de características que exerçam uma função (pré) terapêutica, uma prevenção pré-nascimento, o que representaria um avanço inimaginável quanto à modernidade, mas almejado desde antes dela. Em vez disso, o horizonte que se abriria seria o da eugenia, o da seleção e o da autocriação, o que, para os transumanistas, seria um primeiro passo rumo ao pós-humanismo.

É com esse ponto que nos encaminhamos à conclusão do presente artigo. A forma-Homem-transumana seria o mais novo estágio de forma-Homem. Ou seja, considerando que não haveria $o$ homem, algo perene e imutável, a biotecnociência criaria novas forças e as combinaria de modo inédito, de forma que um novo humano despontaria no horizonte das formas-Homem possíveis. A força-técnica-artificializadora, própria das biotecnociências atuais, encurtaria o hiato entre o humano e o transumano, tornando obsoletas as outras formas de objetivação do homem.

Haja vista os limites citados, parece-nos que há a necessidade de desenvolver um conceito ou conjunto de conceitos que trate especificamente da dimensão 
selecionadora e autocriadora do humano. Para além, ainda que não para aquém, da saúde, o ponto que merece bastante atenção é a capacidade do homem se autoprogramar, especialmente através do biodesign da sua descendência. $\mathrm{O}$ conceito de biodesign, cujos aspectos conceituais lançamos propedeuticamente, orienta a visada noutro sentido: para além da promoção da vida biológica e da gestão dos riscos, tem-se fundamentalmente um modo de autosseleção, autocriação e autoartificialização do homem, com vistas ao planejamento genético e fenotípico de si mesmo e da descendência. Ou seja, a vida se torna uma espécie de coisa rascunhável.

Tornar a vida um objeto de planejamento racional, algo projetável desde as suas origens, retirando da natureza a prerrogativa e o monopólio da seleção e do aperfeiçoamento, assumindo corajosamente o papel de selecionar, sem deixar à sorte ou ao fatalismo da concepção casual a tarefa de determinar mesmo que parcialmente aquilo que se será, é algo que extravasa o espectro daqueles conceitos. Nesse sentido, apresentamos, a título unicamente preliminar, o conceito de biodesign como uma possível saída aos limites apresentados por aqueles conceitos.

Em linhas gerais, o biodesign visa a atender às demandas bioéticas e políticas atinentes ao ato de selecionar características tidas como "secundárias", tais como, cor dos olhos, altura, quantidade de pêlos, composição corporal. Na medida em que tal intervenção constrange a fronteira, arbitrária por sinal, como já apontamos, entre eugenia negativa (terapia) e eugenia positiva (aperfeiçoamento), biodesign não se restringe ao campo da intervenção terapêutica (eugenia negativa), geralmente tida como legítima, pois visaria a apenas impedir o desenvolvimento de características nocivas (afecçooes, doenças, deficiências) à vida "saudável" ou "normal", mas se refere ao campo do aperfeiçoamento (eugenia positiva), o qual é penalizado por ser identificado com sonhos de perfectibilidade do humano.

Aliás, através dele, visamos a problematizar tal distinção, o que nos parece fundamental, já que muitos autores se esmeram nela para criticar o buman enhancement, atacando tanto a sua dimensão de self-design, mas, sobretudo, de other-design. Em síntese, o biodesign se aplica entender a autoartificialização do humano, uma forma de iluminismo de raízes biológicas. Em certo sentido, é como se o humano decidisse corajosamente sair da tutoria ou do pastoreio da natureza no tocante à sua evolução, buscando sair da "menoridade biológica”, assumindo, com isso, a responsabilidade por orientar o futuro da 
natureza humana, o que envolve riscos evidentemente, mas permite avanços extremamente promissores num tempo mais ou menos curto.

Assim, mostra-se pertinente a construção de outros conceitos, como o de biodesign, para compreender a nova genética, haja vista ela trazer possibilidades inéditas acerca da artificialização da vida humana, as quais são irredutíveis aqueles conceitos. O human enhancement, antigo sonho eugênico, parece, como nunca, tangível, especialmente em razão da concretização do biodesign técnico-científico.

\section{Referências}

AGAR, N. Liberal Eugenics: In defense of human enhancement. Oxford: Blackwell Publishing, 2004. 205p.

BOSTROM, N.; SAVULESCU, J. Human enhancement ethics: the state of the debate. In: SAVULESCU, J.; BOSTROM, N. (Orgs.). Human enhancement. Oxford University Press, 2009, p. 1-25.

BUCHANAN, A. et al. From chance to choice. Genetics and justice. Cambridge: Cambridge University Press, 2001. 398p.

BUCHANAN, A. Human nature and enhancement. Bioethics, v. 23, n. 3, 2009, p. 141-150.

DANIELS, N. Can anyone really be talkink about ethically modifying human nature? In: SAVULESCU, J.; BOSTROM, N. (Orgs.). Human enhancement. Oxford University Press, 2009, p. 25-42.

DELEUZE, G. Sobre a morte do homem e o super-homem. In: Foucault. São Paulo: Brasiliense, 2005, p. 132-142.

DIAS, M.C.; VILAÇA, M.M. Metamorfoses do humano: notas sobre o debate ético em torno da biotecnologia para o aperfeiçoamento humano. Ethic@ (UFSC), Florianópolis v. 9, n. 1, p. 29-42, jun. 2010.

DUPUY, J-P. O transumanismo e a absolescência do homem. In: NOVAES, A. (Org.). A condição humana: as aventuras do homem em tempos de mutações. São Paulo: Agir, 2009, p. $89-122$.

FOUCAULT, M. Em defesa da sociedade: curso no Collège de France (1975-1976). São Paulo: Martins Fontes, 2005. 382p.

. Governamentalidade. In: MACHADO, R. (Org.). Microfísica do poder. 24 ed. Rio de Janeiro: Graal, 2007, p. 278-293.

História da sexualidade I: a vontade de saber. Rio de Janeiro: Edições Graal, 2003. 152p. . Segurança, território e população: curso no Collège de France (1977-1978). São

Paulo: Martins Fontes: 2008. 572p. 
GLOVER, J. Choosing children: genes, disability, and design. Oxford: Clarendon Press, 2006. 120p.

HABERMAS, J. O futuro da natureza humana: a caminho de uma eugenia liberal? São Paulo: Martins Fontes, 2004. 159p.

LAFONT, C. Remarks on Habermas's presentation of "L'avenir de la nature humaine". Philosophy and Medicine, v. 3, n. 1, p. 157-160, 2003.

LEWONTIN, R.C. Biologia como ideologia: a doutrina do ADN. Lisboa: Relógio D’água, 1998. 137p.

MURRAY, T. H. Enhancement. In: STEINBOCK, B. (Ed.). The Oxford Handbook of Bioethics. New York: Oxford University Press, 2009, p. 491-515.

RABINOW, P. Artificialidade e iluminismo: da sociobiologia à biossociabilidade. In: BIEHL, J.G. (Org.). Antropologia da razão: ensaios de Paul Rabinow. Rio de Janeiro: Relume Dumará, 1999, p. 135-157.

. Making PCR: a short story of biotechnology. Chicago: The University of Chicago Press, 1996.

SANDEL, M. The case against perfection: ethics in the age of genetic engineering. Cambridge, MA: Harvard University Press, 2007. 161p.

SAVULESCU, J. Procreative beneficence: why we should select the best children. Bioethics, v. 15, issue 5-6, 2001, p. 413-426.

SAVULESCU, J.; KAHANE, G. The moral obligation to create children with the best chance of the best life. Bioethics, v. 23, n. 5, 2009, p. 274-290.

SLOTERDIJK, P. Regras para o parque humano: uma resposta à carta de Heidegger sobre o humanismo. São Paulo: Estação Liberdade, 2000. 63p.

VALENZUELA, J.G. Genoma humano y dignidad humana. Barcelona: Anthropos Editorial, 2005. 252p.

WATSON, J.D.; BERRY, A. DNA: The secret of life. New York: Random House, 2003. 446p.

\section{Nota}

${ }^{1}$ Julian Savulescu, Tanner Lectures on Human Values, Oxford University, 2009. Disponível em: $<$ http://www.practicalethics.ox.ac.uk/ppt/tanner_2009_enhancementhumanright.ppt $>$. Acesso em: 20 set 2010 . 


\section{The new genetics beyond of risk management and promotion of health: introduction to the concept of Biodesign}

The new genetics would point to a new era of metamorphosis of the human, which would be marked by the prominence of that in the selection and improvement of their nature. Thus, the Human Enhancement would become a tangible reality anthropo-technique. This paper, included a research of the field of Ethics Enhancement of Human Beings, intends excogitate a new concept to understand nuances called Genetic Age apparently overlooked by other already available, namely, Biopolitics and Biosociality. Therefore, we refer the review of the bibliography on Human Enhancement and the analysis and critique of these concepts, which focus on the issue mainly of risk management and promotion of healthy living. The objective was to identify the partial relevance of the grid of intelligibility provided by them to understand the new genetics. So, we present an introductory the concept of Biodesign as a complementary alternative, hoping that it permits the apprehension, especially, what the possibilities of artificiality of life to represent beyond a new form of risk management/health promotion.

> Key words: new genetic; risk management; biopolitics; biosociality; biodesign. 